\title{
METACOGNITIVE SKILLS IN MATHEMATICS PROBLEM SOLVING
}

\author{
Wahyu Lestari ${ }^{1)}$, Loviga Denny Pratama ${ }^{2)}$, Jailani ${ }^{3)}$ \\ ${ }^{1,2}$ Tadris Matematika, Institut Ilmu Keislaman Zainul Hasan \\ ${ }^{3}$ Program Studi Pendidikan Matematika, Universitas Negeri Yogyakarta \\ ${ }^{1}$ E-mail: why.lestari94@gmail.com
}

\begin{abstract}
This study is a descriptive qualitative approach. The purpose of this study was to describe level metacognitive skills of students in solving the problem solving test item based on indicators that had been compiled. Metacognitive skills in this study form planning, monitoring, reflection aspect. Data analysis aimed to describe the students' metacognitive skills. Then, the researcher categorized the students' metacognitive skills into reflective use, strategic use, aware use, and tacit use. The data collection methods in this study were documentation, test, and interview. From 40 student spread across many Junior High Schools in Jember district, 8 students are found to be able reading and writing of what was known (P-1), determining solving strategies (P-2), Using rules (M-1), and monitoring carefully (M-2), thus classified as having metacognitive skills into aware use. Furthermore, 20 students are able to perform (P-1), (P-2), planning intermediate results (P-3), (M-1), (M-2), able to correct mistake (M-3), and Reflecting achievement of the objectives (R-1), thus classified as having metacognitive skills into strategic use. Furthermore, 12 students are able to perform (P-1), (P-2), (P-3), (M-1), (M-2), (M-3), (R-1), do wareness on the application/use of strategies (R-2), analyze the text/formula (R-3), choosing intentionally the representation ( $\mathrm{R}-4)$, thus classified as having metacognitive skills into reflective use.
\end{abstract}

Keywords: metacognitive skills, problem solving, reflective use, strategic use, aware use

\section{INTRODUCTION}

Students ability to apply mathematics in daily life is seen as a core goal of mathematics education (e.g., Graumann, 2011; Muller \& Burkhardt, 2007; Niss, Blum, \& Galbraith, 2007). Indeed, it has been recommended that mathematics should be learned by problem-solving (National Council of Teachers of Mathematics, 2000). Problem solving is an activity simulated problem situations provide context and reason for learning mathematics. Considering the importance of problem solving in learning mathematics including in Indonesia, but in several studies, students still have difficulties in solving context based tasks (e.g., Wijaya, van den Heuvel-Panhuizen, \& Doorman, 2015). The findings suggest give teaches students for comprehending a real-world problem and it might be an important key to improve students' performance mathematics in daily life.

Each student has different ability in solving the problem (e.g., Abubakar, 2016; Kurniati, Mukti, \& Jamil, 2016; Wijaya, Heuvel-panhuizen, Doorman, \& Robitzch, 2014). Some students consciously pay attention to the given problem by solving it in hierarchical way, but there are also students who just carelessly answer the problem when facing the test. Based on the research result, it can be stated that each student has different process of thinking or plan of thinking in solving the problem. Therefore they require different instruction(Retnowati, 2016). In sum, teachers should make use strategies of mathematics instructions by 
which students can dominate mathematics knowladge underpinning the problem solving.

Studies on metacognition have proven that there is a strong correlation between problem solving and metacognition (see Gurat \& Medula, 2016). Therefore, teachers should employ metacognition to students in the process of mathematical problem solving. During these years, metacognition became a successful appliance for researcheres investigating thinking processes (see Brown \& Day, 1983; Campione, Brown, \& Connell, 1989; Garofalo \& Lester, 1985; Schoenfeld, 1987). There are different classify about metacognition, namely: metacognitive skills, metacognitive experience and metacognitive knowladge (Gurat \& Medula, 2016). Swartz \& Perkins (1989) have identified level metacognition of student in the process of thinking processes, as follow.

(1) Tacit use is the use of thought without unconsciousness. The type of thought that relates to decision making without thinking about that decision. In this case, students apply the strategy or skill without a certain consciousness or by using trial and error and carelessly answer the question in solving the problem.

(2) Aware use is the use of thought with consciousness. The type of thought that relates to the students' consciousness about what and why they do the thought. In this case, students are aware that they have to use a problem solving step by explaining why they choose to use that step.

(3) Strategic use is the use of strategic thought. The type of thought that relates to the individual systematization in his/her thinking process consciously by using specific strategies that can improve the accuracy of his/her thinking. In this case, students are aware and able to select specific strategies or skills to solve the problem.

(4) Reflective use is the use of reflective thought. The type of thought that relates to individual reflection in the thinking process before and after or even during the ongoing process by considering the continuation and improvement of the thinking result. In this case, students realize and correct their mistake they do in the steps of problem solving.

(5) In this article, the researcher analyzed the students' metacognition in solving problem-solving question. The analysis result was grouped based on the level of students' metacognitive skills.

\section{RESEARCH METHOD}

This study is a descriptive qualitative. This study analyzed the students' metacognitive skills which consisted of planning, monitoring, and reflection in completing problem solving question. Description and categorization of students' metacognitive skills level were the main target of this research. The subjects were the students of schools in Jember, both public and private school. Each school was represented by two seventh grade students of Junior High School (see Figure 1).

Figure 1. Research Procedure

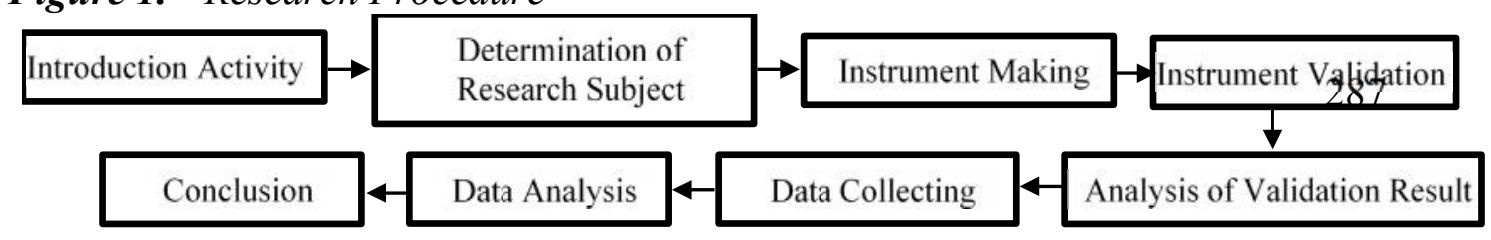


The initial stage in this study was introduction activity stage. In this stage, the researcher found the place of research which were some Junior High Schools in Jember. After determining the place of research, the researcher determined the research subject. The subjects were forty seventh graders of Junior High School.

In a research, there should be a valid research instrument. Before conducting the research, a researcher must make a research instrument. The instruments included scoring rubric, problem solving test and manual of interview. Those instruments were validated by the validator. After obtaining the validation result, the researcher analyzed it to find out their validity level. If the instruments are valid, they can be used for the research stage or data collecting. In this stage, the researcher conducted a test of problem solving to find out the students' metacognitive skills level. The test material in this study was quadrilateral. After conducting the test, the researcher interviewed the students.

The next stage was data analysis. At this stage, the researcher analyzed the students' answer on the problem solving test and the interview. The analysis aimed to describe the students' metacognitive skills. Then, the researcher categorized the students' metacognitive skills into reflective use, strategic use, aware use, and tacit use (Swartz \& Perkins, 1989). The steps are as follow. Firstly, finding the minimum score by multiplying the number of the test problems by the lowest score of scoring rubric for metacognitive skills. Secondly, finding the maximum score by multiplying the number of the test problems with the highest score in each metacognitive skills. Thirdly, determining the range. The last, dividing the range into 3 parts to obtain the class interval.

\section{RESULT AND DISCUSSION}

The subjects of research were 40 students of several Junior High Schools in Jember. They participated a problem solving test and an interview at a predetermined time. The test and interview included the aspect of planning, monitoring, and reflection. The test scores for the highest and the lowest were 47 and 16 respectively. The categorization of students' metacognitive skills level was made based on the score (see table 1). The obtained research result was, out of 40 subjects of research, there were 8 students of upper group, 20 students of middle group and 12 students of lower group.

Table 1. Student Grouping based on the Distribution of Standard Deviation

\begin{tabular}{lcc}
\multicolumn{1}{c}{ Value } & & \\
\hline \multicolumn{1}{c}{ Students' Score (NS) } & Category & Percentage \\
\hline$N S \geq 41,77$ & Upper & $13.51 \%$ \\
$26,44<N S \geq 41,77$ & Middle & $62.16 \%$ \\
$N S \leq 26,44$ & Lower & $24.32 \%$ \\
\hline
\end{tabular}

The test was given in the form of problem solving test. It consisted of 5 problems. The following is the explanation of the data analysis of the students' work represented the metacognitive skills in upper, middle and lower category.

\section{Planning Aspect}

Figure 1 is one of students' works of the upper, middle and lower group in planning aspect. The students of the upper, middle and lower group always began the problem solving by expressing the problem then writing what were known and 
asked in the problem (P-1). The ability to distinguish what are known and what are unknown is an important thing to reach success in all academic setting (Tobias \& Everson, 2002).

Figure 2. Example of Students Answer number 1

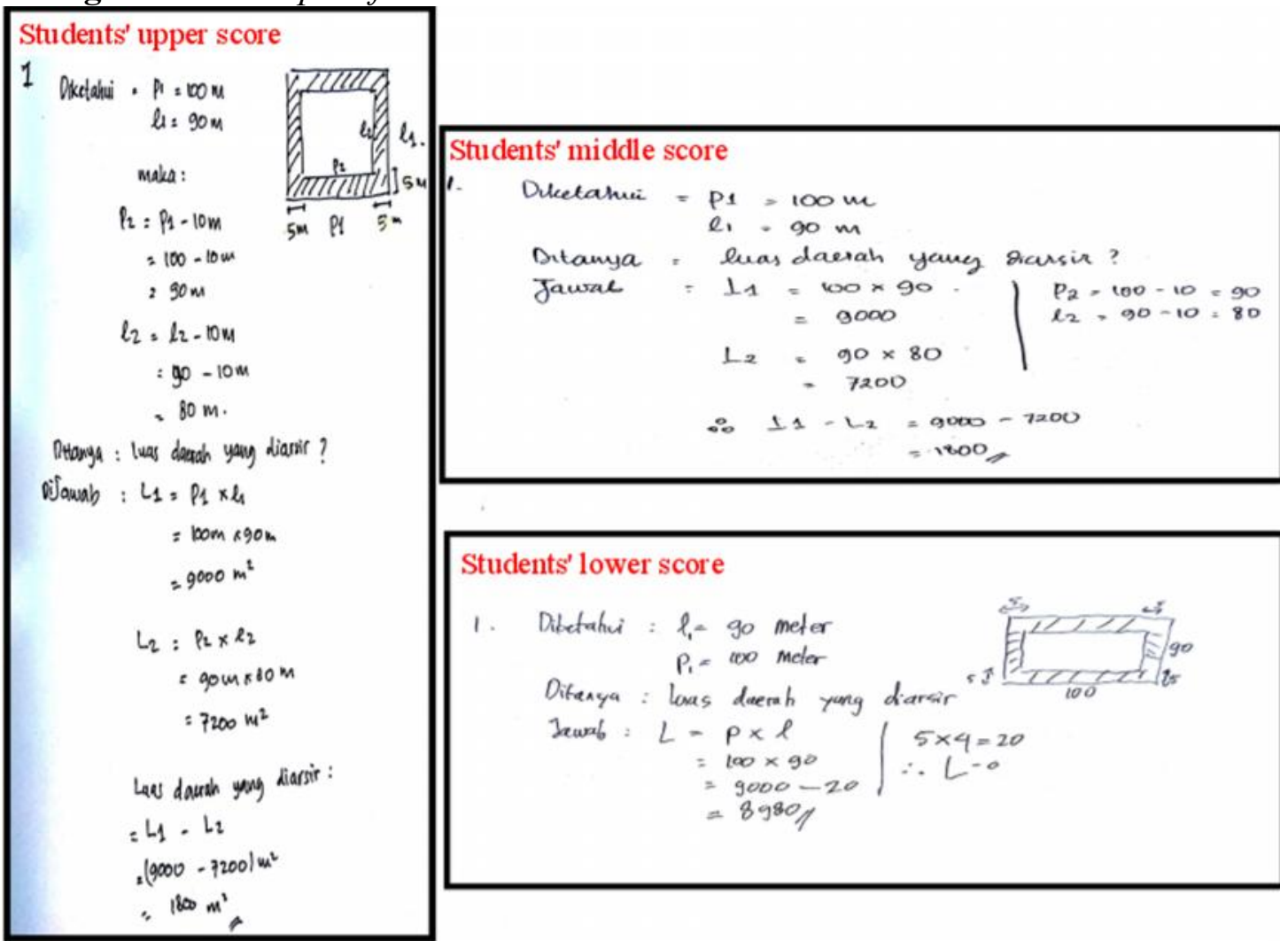

Those three groups also determined the strategy in solving the problem (P2). As seen in Figure 1, students had written the formula of rectangle. However, the lower group students did a mistake in doing the strategy in solving the problem. Woolfolk, Hughes, \& Walkup (2008) state that the selection of what strategy will be used, how to start, and which one that should be chosen or used first include in the realm of planning metacognitive skills in solving problem.

The result determination of problem solving (P-3) was only performed by students in the upper and middle group. This is similar to (Gok, 2010) research result which states that in solving problem, students have to simplify the problem by drawing diagram or simple object sketch and stating what is wanted to find mathematically. Figure 2 shows that students divide the shaded area to four parts. The two parts had the size of $100 m \times 5 m$ and the other two parts had the size of $90 m \times 5 m$.

\section{Monitoring Aspect}

Metacognitive aspect uses the rules (M-1) that were performed by the three groups. This aspect is in line with (Pulmones, 2007) statement that metacognitive manifestation of monitoring dimension can be: using picture, making diagram, making table, writing on small note, and etc. On one of problem 
solving questions of looking for a trip route (see Figure 2), students were able to project the problem to be a picture. So that the picture can facilitate them in performing completion.

Figure 3. Example of Students Answer number 4

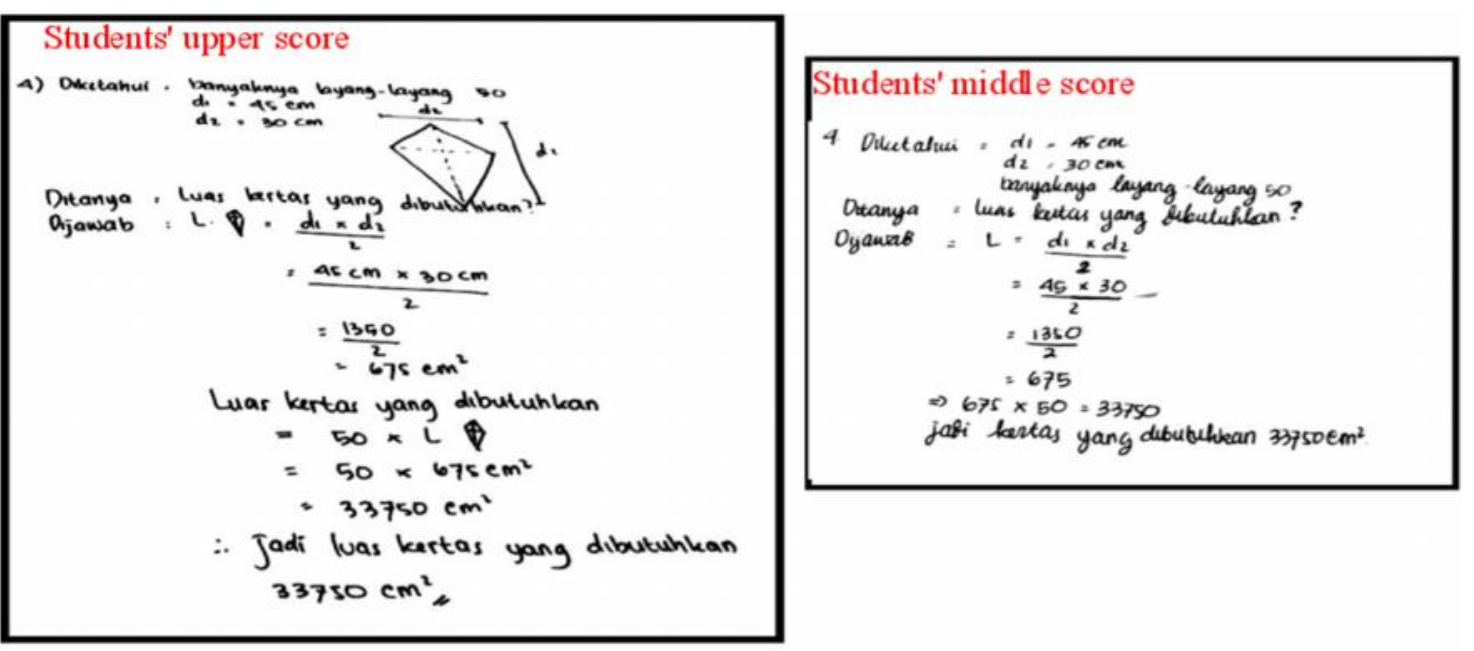

$$
\begin{aligned}
& \text { Students' lower score } \\
& \text { 4. Ditetahui }=\quad \begin{array}{l}
d_{1}=45 \text { centineter } \\
d_{2}=30 \text { centimeter }
\end{array} \\
& \text { bapngat = so } \\
& \begin{array}{l}
\text { Ditanza }=\text { Luas kertas yang diperlutur } \\
\text { Jawab }=L=\frac{45 \times 30 \times 50}{2}
\end{array} \\
& =33250
\end{aligned}
$$

Based on the interview, those three groups did a monitoring activity on something that was considered as a mistake (M-2). In this case, the subjects were aware of what mistake they made. The lower group students did a mistake in converting the unit (see Figure 3). Rivers (2001) states that students who are skilled in assessing themselves are students who are aware of their ability.

The other activity performed by the upper and middle group subjects were able to correct the mistake (M-3) in solving the problem. The monitoring activity is a direct awareness about how we do a cognitive activity (Woolfolk et al., 2008) and one of the monitoring activities is a dimension manifestation of checking progress against goals or to-do list (Pulmones, 2007). This argument is reinforced by Polya (1973) statement which states that the activity of investigating the solving steps aims to check whether the steps done are correct or they can be proven that they are correct.

The monitoring of problem solving by giving argument (M-4) was only performed by the upper group students. They gave explanation "before finding out the area of the needed paper for kite, we need to calculate the area of the kite's base first". This activity is based on (Cohors-Fresenborg \& Kaune, 2007) opinion which states that metacognitive aspect on monitoring aspect can be in the form of monitoring the problem solving by giving argument. Furthermore, Jacobs \& Paris 
(1987) state that monitoring dimension is a conscious monitoring activity on the ongoing task performance.

Figure 4. Example of Students Answer number 5

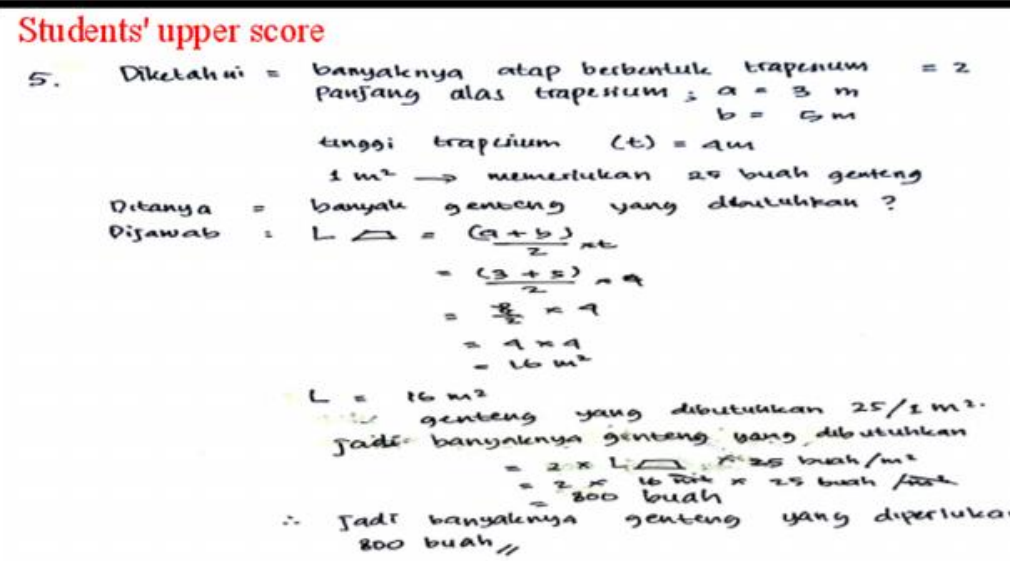

Students' middle score

5

Occetarui $=a=3 \mathrm{~m}$

$b=5 \mathrm{~m}$

$t=\Delta \mathrm{m}$

banyalenya atap 2

$1 \mathrm{~m}^{2}$ depertween

$L=(a+b) \times t$

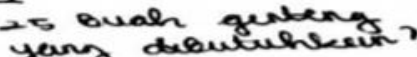

Dutanyen $=$
Dycunab $=$

a

$=\frac{(3+5) \times 4}{2}$

$=16 \mathrm{~m}^{2}$

Akhurnya $16 \times 25=400=$

\section{Reflection Aspect}

The activity of reflection metacognitive was performed by the upper and middle group students in the form of evaluation on the achievement of problem solving purpose (R1). They were able to state the number of the roof tile needed in the problem solving (see Figure 4). Pulmones (2007) shows that reflection can be in the form of rechecking whether the purpose is achieved, reflecting which learning strategy is more efficient, assessing how the learning strategy is applied on the other contexts as well as self-respecting after learning and completing the task. Besides, the upper and lower group also did awareness on the application/use of strategy (R2). They did this when they decided to calculate the area of trapezoid first in determining the number of the roof tile needed in the problem.

Another metacognitive activity performed by the upper group students were analyzing mathematical symbol (R3). In the problem, they were able to do operating a unit of length namely $\mathrm{m}^{2}$ so that they obtained the right result in unit of length. This was not performed by the lower and middle group students. Another reflection aspect performed by the upper and middle group were making deliberate choice (R4) in the form of choosing strategy in solving the problem so 
that they were able to determine the solving. This indicates that during the solving, students were intensive enough in monitoring their own knowledge development to ensure that the solving strategy they performed is appropriate.

The upper group was able to do reflecting in solving the problem based on Boud, Keogh, \& Walker (1985) opinion which states that reflecting is an activity in which someone recapture his/her experience, rethink, re-consider and re-reflect it. Someone who is able to re-reflect his/her thought on what is being thought does not only understand what he/she knows well, but also able to make conscious decision and able to correct his/her mistake. From the result of the explanation, the subject on the upper was presumed to be on the reflective use level. This is in line with the theory of Swartz \& Perkins (1989) that reflective use is a use of reflective thought. In this case, students realize and correct their mistake they did in the steps of solving the problem.

The middle group showing the metacognitive activity of planning and monitoring dimension was presumed to be on the strategic use level. This is in line with the theory of Swartz \& Perkins (1989) that strategic use is the use of thought related to the individual setting in their thinking process consciously by using particular strategies than can improve their thinking accuracy. In this case, students were aware and able to choose a strategy or particular skill to solve the problem. The dimension of reflection was performed by the upper and middle group students, but was not performed by the lower group students because they were not able to manage time. This is based on the research finding which states that reflecting takes more time (e.g., Rambusch, 2006; Sugiarto, Prabowo, \& Suyono, 2014).

In the lower group was able to understand the problem by writing of what was known to the problem. Furthermore, they were able to use concept/formula and realize concept errors but they did'n know how to fix it. We found that generally the lower group students made more comprehension errors and confusion in choosing a settlement strategy than the upper grup students. From the result of the explanation, the subject on the lower was presummed to be on the aware use level.

Based on the result and discussion above, it can be arranged categorization of students's matacognitive skills level in mathematics problem solving especially on quadrilateral material.

Table 2. Categorization of Students' Metacognitive Skills Level

\begin{tabular}{|c|c|c|c|c|c|c|c|c|c|}
\hline \multirow{3}{*}{$\begin{array}{c}\text { metacognitive } \\
\text { skills Level }\end{array}$} & \multicolumn{9}{|c|}{ Aspect of Metacognitive skills } \\
\hline & \multicolumn{3}{|c|}{ Planning } & \multicolumn{3}{|c|}{ Monitoring } & \multicolumn{3}{|c|}{ Reflection } \\
\hline & $\mathrm{U}$ & $\mathrm{M}$ & $\mathrm{L}$ & $\mathrm{U}$ & $\mathrm{M}$ & $\mathrm{L}$ & $\mathrm{U}$ & $\mathrm{M}$ & $\mathrm{L}$ \\
\hline \multirow[t]{4}{*}{ Reflective Use } & P-1 & & & M-1 & & & R-1 & & \\
\hline & P-2 & & & M-2 & & & R-2 & & \\
\hline & P-3 & & & M-3 & & & $\mathrm{R}-3$ & & \\
\hline & & & & M-4 & & & $\mathrm{R}-4$ & & \\
\hline \multirow[t]{3}{*}{ Strategic Use } & & $\mathrm{P}-1$ & & & M-1 & & & $\mathrm{R}-1$ & \\
\hline & & P-2 & & & M-2 & & & & \\
\hline & & P-3 & & & M-3 & & & & \\
\hline Aware Use & & & P-1 & & & M-1 & & & \\
\hline
\end{tabular}




\section{P-2}

Tacit Use

Annotation
$\begin{array}{ll}\mathrm{U} & \text { : Upper group students } \\ \mathrm{M} & \quad \text { : Middle group students } \\ \mathrm{L} & \text { : Lower group students } \\ \mathrm{P}-1 & \text { : reading and writing of what was known } \\ \mathrm{P}-2 & \text { : determining solving strategies } \\ \mathrm{P}-3 & \text { : planning intermediate results } \\ \mathrm{M}-1 & \text { : Using rules } \\ \mathrm{M}-2 & \text { : Monitoring carefully } \\ \mathrm{M}-3 & \text { : able to correct mistake } \\ \mathrm{M}-4 & \text { : Monitoring by arguing } \\ \mathrm{R}-1 & \text { : Reflecting achievement of the objectives } \\ \mathrm{R}-2 & \text { : do wareness on the application/use of strategies } \\ \mathrm{R}-3 & \text { : analize the text/formula } \\ \mathrm{R}-4 & \text { : choosing intentionally the representation }\end{array}$

\section{CONCLUSSIONS}

Based on the result and discussion, metacognitive skills performed by lower group students were able to able reading and writing of what was known (P1), determining solving strategies (P-2), Using rules (M-1), and monitoring carefully (M-2), thus classified as having metacognitive skills into aware use. Furthermore, middle group students were able to perform (P-1), (P-2), planning intermediate results (P-3), (M-1), (M-2), able to correct mistake (M-3), and Reflecting achievement of the objectives (R-1), thus classified as having metacognitive skills into strategic use. Furthermore, upper group students were able to perform (P-1), (P-2), (P-3), (M-1), (M-2), (M-3), (R-1), do wareness on the application/use of strategies (R-2), analyze the text/formula (R-3), choosing intentionally the representation (R-4), thus classified as having metacognitive skills into reflective use.

In sum, this study gave insight into metacignitive skills of students in the discplines of mathematics. Furthermore, this study can also be used a material consideration in planning learning model or strategy that aims to optimize and improve students's ability in mathematics problem solving. However, when making use of the findings this study should be done with prudence, because this study clearly has some limitations that need to be taken into account. What we found in this Indonesian sample does not necessarily apply to students in other countries with different educational practices. For example, about the problem are not necessarily relevant for students in other countries. 


\section{REFERENCES}

Abubakar, W. (2016). Analytical Problem Solving Skill at Social Arithmetic in Project Based Learning in Grade 3 SMP Islam Athirah Bukit Baru. JURNAL DAYA MATEMATIS, 4(3), 380-392.

Boud, D., Keogh, R., \& Walker, D. (1985). Promoting reflection in learning: A model. London: Kogan.

Brown, A. L., \& Day, J. . (1983). Macrorules for summarizing texts. The development of expertise. Journal of Verbal Learning and Verbal Behavior, 22, 1-14.

Campione, J. C., Brown, A. L., \& Connell, M. L. (1989). Metacognition: On the importance of understanding what you are doing. In R. I. Charles, E. A. Silver, \& (Eds.) (Eds.), The teaching and assessing of mathematical problem solving (pp. 93-114).

Cohors-Fresenborg, E., \& Kaune, C. (2007). Modelling classroom discussion and categorizing discursive and metacognitive activities. In Proceeding of CERME (pp. 1180-1189).

Garofalo, J., \& Lester, F. . (1985). Metacognition, Cognitive Monitoring, and Mathematical performance. Journal for Research in Mathematics Education, 16(3), 163-176.

Gok, T. (2010). The General Assessment of Problem Solving Processes and Metacognition in Physics Education. Eurasian Journla of Physics and Chemistry Education, 2(2), 110-122.

Graumann, G. (2011). Mathematics for problems in the everyday world. Realworld problems for secondary school mathematics students: Case studies (J. Maasz \&). Rotterdam: Sense Publishers.

Gurat, M. G., \& Medula, C. T. (2016). Metacognitive Strategy Knowledge Use through Mathematical Problem Solving amongst Pre-service Teachers. American Journal of Educational Research, 4(2), 170-189. https://doi.org/10.12691/education-4-2-5

Jacobs, J. E., \& Paris, S. G. (1987). Children's Metacognition About Reading: Issues in Definition, Measurement, and Instruction. Educational Psychologist, 22(3-4), 255-278. https://doi.org/10.1080/00461520.1987.9653052

Kurniati, D., Mukti, R. H., \& Jamil, N. A. (2016). Kemampuan Berpikir Tingkat Tinggi Siswa SMP di Kabupaten Jember dalam Menyelesaikan Soal Berstandar PISA. Jurnal Penelitian Dan Evaluasi Pendidikan, 3(11), 555584.

Muller, E., \& Burkhardt, H. (2007). Applications and Modelling for Mathematics - Overview. In B. W., G. P.L., H. HW., \& N. (Eds) M. (Eds.), Modelling and Aplications in Mathematics Education (pp. 267-274). Boston, MA: Springer.

National Council of Teachers of Mathematics. (2000). Principles and Standards for School Mathematics. Reston: NCTM.

Niss, M., Blum, W., \& Galbraith, P. (2007). Introduction. In W. Blum, P. L. Galbraith, H.-W. Henn, \& M. N. (Eds.) (Eds.), Modelling and Applications in Mathematics Education (pp. 3-32). New York: Springer. 
Polya, G. (1973). How to solve it (2nd ed.). New Jersey: Princeton University Press.

Pulmones, R. (2007). Learning chemistry in a metacognitive environment. AsiaPacific Education Researcher, 16(2), 165-183. https://doi.org/10.3860/taper.v16i2.258

Rambusch. (2006). Situated Learning and Galperin's Notion of Object-Oriented Activity. Sweden: University of Skovde.

Retnowati, E. (2016). SEAMEO Qitep in mathematics. Yogyakarta.

Rivers, W. P. (2001). Autonomy at all costs: An ethnography of metacognitive self-assessment and self-management among experienced language learners. Modern Language Journal, 85(2), 279-290. https://doi.org/10.1111/0026-7902.00109

Schoenfeld, A. H. (1987). What's all the fuss about metacognition? In A. H. (ed. . Schoenfeld (Ed.), Cognitive Science and Mathematics Education (pp. 19216). NJ: Erlbaum, Hillsdale.

Sugiarto, Prabowo, \& Suyono. (2014). Students' Metacognitive Self-Regulation A Case Study: Molecular Structure Problem Solving. Chemistry: Bulgarian Journal of Science Education, 23(3), 374-391.

Swartz, R., \& Perkins, D. (1989). Teaching thinking: Issues and approaches. Pacific Grove, CA: Midwest Publications.

Tobias, S., \& Everson, H. (2002). Knowing what you know and what you don't further research on metacognitive knowladge monitoring. New York: College Board.

Wijaya, A., Heuvel-panhuizen, M. Van Den, Doorman, M., \& Robitzch, A. (2014). Difficulties in solving context-based PISA mathematics tasks : An analysis of students ' errors. The Mathematics Enthusiast, 11(3), 555-584. Retrieved from http://staff.uny.ac.id/sites/default/files/penelitian/ariyadiwijaya-dr/wijaya2014students-difficulties.pdf

Wijaya, A., van den Heuvel-Panhuizen, M., \& Doorman, M. (2015). Opportunityto-learn context-based tasks provided by mathematics textbooks.

Educational Studies in Mathematics, 89(1), 41-65. https://doi.org/10.1007/s10649-015-9595-1

Woolfolk, A., Hughes, M., \& Walkup, V. (2008). Psychology in education. London: Pearson. 